WORKING PAPER - NO. 2020-46

\title{
Childcare Obligations Will Constrain Many Workers When Reopening the US Economy
}

Jonathan I. Dingel, Christina Patterson, and Joseph Vavra

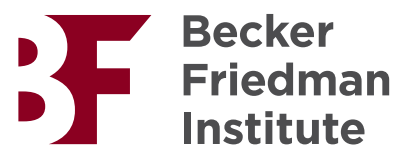




\title{
Childcare obligations will constrain many workers when reopening the US economy*
}

\author{
Jonathan I. Dingel \\ Chicago Booth, NBER, and CEPR \\ Christina Patterson \\ Northwestern and NBER \\ Joseph Vavra \\ Chicago Booth and NBER
}

April 2020

Most states and cities in the U.S. have shut all non-essential businesses in response to COVID19. In this note, we argue that as policies are developed to "re-open" the economy and send people back to work, strategies for childcare arrangements, such as re-opening schools and daycares, will be important. Substantial fractions of the U.S. labor force have children at home and will likely face obstacles to returning to work if childcare options remain closed. ${ }^{1}$ Younger workers, who might be able to return to work earlier to the extent that they are less susceptible to the virus, are also more likely to require childcare arrangements in order to return to work.

Using 2018 data from the Census Bureau's American Community Survey, we calculate the share of employed households who are affected by childcare constraints. ${ }^{2}$ We focus on the civilian employed population older than 18.

The first row in Table 1 shows that 32 percent of that workforce has someone in their household who is under 14. Thus, 50 million Americans must consider childcare obligations when returning to work. Daycares and pre-schools might open sooner than primary schools, since they tend to have fewer children and thus less scope for disease transmission, so the remaining columns of Table 1 distinguish children under 6 and those 6-14 years old. For about 30 percent of the workforce with childcare requirements, all of their children are under the age of 6 . Thus, opening daycares alone could address childcare obstacles for one in three constrained workers.

Of course, many workers with children at home are not sole caregivers. Workers who live in a household with another non-working adult - such as a partner who is not employed, a retired

*Dingel thanks the James S. Kemper Foundation Faculty Research Fund at the University of Chicago Booth School of Business. jdingel@chicagobooth.edu, christina.patterson@northwestern.edu, and joseph.vavra@ chicagobooth.edu.

${ }^{1}$ We explicitly refrain from any evaluation of public-health considerations related to school closures since we have no expertise in this area. We instead seek to focus solely on measuring economic constraints that arise in a phased employment recovery. It is entirely possible that these constraints may be unavoidable for public-health reasons.

${ }^{2}$ Alon et al. (2020) use ACS data to compute a number of closely related statistics, but they focus on measuring household childcare burdens while we use employed workers as our unit of analysis and focus specifically on measuring the importance of childcare constraints for aggregate, regional, and industry employment. 
Table 1: Childcare Obligations of the Workforce

\begin{tabular}{|c|c|c|c|c|}
\hline & $\begin{array}{l}\text { Children } \\
\text { under } 14\end{array}$ & $\begin{array}{l}\text { All kids } \\
\text { age } 6-14\end{array}$ & $\begin{array}{l}\text { All kids } \\
\text { under } 6\end{array}$ & $\begin{array}{c}\text { Kids in both } \\
\text { age ranges }\end{array}$ \\
\hline $\begin{array}{l}\text { Share of workforce with child } \\
\text { in household }\end{array}$ & 0.323 & 0.155 & 0.094 & 0.073 \\
\hline $\begin{array}{l}\text { Share of workforce with child and } \\
\text { no available caregiver in household }\end{array}$ & 0.214 & 0.107 & 0.063 & 0.045 \\
\hline $\begin{array}{l}\text { Share of workforce with household } \\
\text { childcare obligations }\end{array}$ & 0.112 & 0.057 & 0.032 & 0.024 \\
\hline $\begin{array}{l}\text { Share of under-55 workforce with } \\
\text { household childcare obligations }\end{array}$ & 0.136 & 0.067 & 0.040 & 0.029 \\
\hline
\end{tabular}

Notes: The share of the workforce with no available caregiver in household is defined as the share of workers with no non-employed household member. The share of the workforce with household childcare obligations is defined as the share of workers who would have to remain home so that each household with a child would have at least one adult at home.

parent or in-law, or an older child above 18 who lives at home - can likely return to work while another household member addresses their childcare needs. The second row of Table 1 reports the share of all workers who live in a household with someone under 14 and no available caregiver. If non-working adults can assume household childcare responsibilities, 21 percent of the workforce would nonetheless have unaddressed childcare obligations.

Although 21 percent of the workforce will face some childcare burden when schools and daycares remain closed, some of them may resume work while other workers in their household address childcare needs. In particular, many workers with children live in households with other workers. Each household would potentially only need one adult to remain home with the children, freeing up the other adults to return to work. The third row of Table 1 shows that accounting for these childcare options leaves 11 percent of the workforce (or 17.5 million workers) facing major barriers to work if schools and daycares remain closed.

The White House and various other commentators have proposed a phased reopening of the economy in which initially only younger, less vulnerable workers return to work. ${ }^{3}$ Schools, daycares, and camps are proposed to open in later phases. Since older patients are more vulnerable to COVID19 , this would potentially balance the health risks for the most at-risk population while promoting economic activity. However, the obstacles to returning to work imposed by school closings are somewhat higher for the under 55 population, because 40 percent of these workers have a child at home. Table 1 shows that 14 percent (or roughly one in seven) of workers under 55 would likely face childcare-related obstacles to returning to work (even after accounting for the fact that in this scenario, workers over 55 in the household could then provide childcare). Under a policy where

\footnotetext{
${ }^{3}$ http://www. whitehouse.gov/openingamerica
} 
young workers return to work while schools remain closed, 35 million workers who are over 55 would not be able to return to work and another 16 million who are under 55 would be constrained by childcare obligations.

The obstacles that childcare imposes on workers during the COVID-19 crisis is similar across industries. Table 2 shows the key statistics for each broad industry category: the share of workers without within-household child care would only range from 18 percent in transportation to 25 percent in education and health care.

Table 2: Workforce Childcare Obligations by Industry

\begin{tabular}{|c|c|c|}
\hline \multirow[b]{3}{*}{ Total } & \multicolumn{2}{|c|}{ Share of workforce in each industry with: } \\
\hline & Child under 14 & $\begin{array}{l}\text { Child under } 14 \text { and } \\
\text { no available caregiver }\end{array}$ \\
\hline & 0.323 & 0.214 \\
\hline Agriculture & 0.361 & 0.204 \\
\hline Construction & 0.371 & 0.198 \\
\hline Manufacturing & 0.324 & 0.202 \\
\hline Wholesale & 0.317 & 0.203 \\
\hline Retail & 0.292 & 0.183 \\
\hline Transportation & 0.317 & 0.182 \\
\hline Utilities & 0.329 & 0.215 \\
\hline Information & 0.295 & 0.199 \\
\hline Finance & 0.320 & 0.231 \\
\hline Professional & 0.319 & 0.213 \\
\hline Education/Child Care & 0.319 & 0.251 \\
\hline Health Care/Assistance & 0.341 & 0.247 \\
\hline Arts/Recreation & 0.310 & 0.197 \\
\hline Other Services & 0.314 & 0.207 \\
\hline Public Administration & 0.329 & 0.237 \\
\hline
\end{tabular}

Figure 1 depicts spatial variation in the share of workers with childcare obligations and no available caregiver in their household. While this figure is as low as 13 percent and as high as 33 percent for some commuting zones, the vast majority of regions are near the national average of 21 percent. Thus, addressing childcare obligations as part of "re-opening" strategies is an important consideration for policymakers across the United States.

These results suggest that childcare-related constraints imposed by school closings should feature prominently in discussions of reopening the economy. While there is scope for a large rebound in employment even if schools and daycares remain closed, the economy will remain 17 million workers short of normal employment in this scenario. Furthermore, many of those working when schools are closed will only be able to do so if a spouse or partner or who would typically be working instead remains home. The longer school closures persist into the recovery of the economy, the 
Figure 1: Share of workers with childcare obligations and no available caregiver by commuting zone

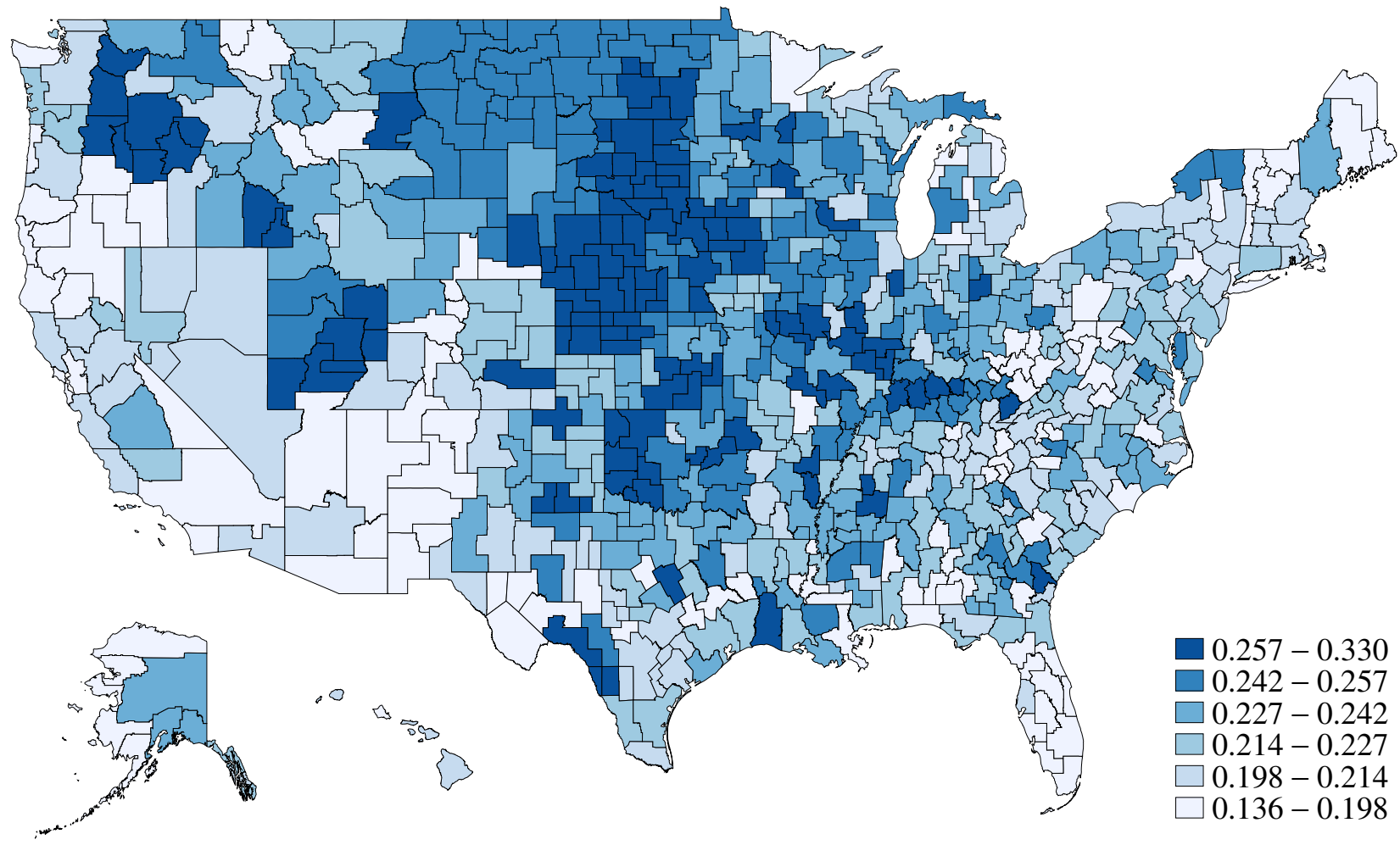

greater will be the burden faced by those workers with young children and no obvious childcare options. We again note that we are making no attempt to evaluate any public-health benefits of school closures or make any assessment of when schools should be reopened. Public-health policies that mitigate the spread of the virus likely have high returns for the ultimate shape of any economic recovery. We instead simply note that discussions of returning to work ought to include discussion of returning to school.

\section{References}

Alon, Titan, Matthias Doepke, Jane Olmstead-Rumsey, and Michele Tertilt. 2020. "The Impact of COVID-19 on Gender Equality." Covid Economics: Vetted and Real-Time Papers, 1(4). 